International Research Journal of Engineering, IT \& Scientific Research
Available online at https://sloap.org/journals/index.php/irjeis/
Vol. 7 No. 6, November 2021, pages: 214-218
ISSN: 2454-2261
https://doi.org/10.21744/irjeis.v7n6.1952

\title{
CT-Scan Patient Dose Monitoring on Thorax Examination in General Hospital Sanjiwani Gianyar
}

\author{
I Gusti Agung Ayu Ratnawati ${ }^{a}$ \\ Ni Luh Putu Trisnawati ${ }^{b}$ \\ Gusti Ngurah Sutapa ${ }^{c}$
}

\section{Article history:}

Submitted: 27 August 2021

Revised: 09 September 2021

Accepted: 18 October 2021

Keywords:

CTDIVol;

$D L P$;

dosage monitoring;

optimization;

\begin{abstract}
Currently, in the world of medicine, the use of medical devices is very important. Along with the development of technology, the need for imaging in radio diagnostics is getting higher. This can be seen from the increasing trend of using medical devices by experts that are tailored to the needs of patients. The progress of radiological examination is growing rapidly with the use of radiation sources, one of which is by using a CT-Scan (Computed Tomography Scanning). The use of CT-Scans must be monitored to ensure the protection and safety of workers, patients, and the public. Protection requirements that must be met in the use of radiation are optimization of radiation protection and safety. The optimization of radiation protection is determined from the diagnostic guide level or the Indonesian Diagnostic Reference Level (I-DRL). The data used in this study is a chest contrast examination with the category of adults (15 years and over). From the CTScan irradiation, the CTDI ${ }_{\mathrm{Vol}}$ and DLP values were determined in the 3rd quartile (Q3=75 percentile). The results showed that the $\mathrm{CTDI}_{\mathrm{Vol}}$ value of $15.79 \mathrm{mGy}$ and DLP of $805.80 \mathrm{mGy} . \mathrm{cm}$ was the dose value that was still following the national I-DRL value that had been determined based on BAPETEN Regulation No. 1211/K/V/2021.
\end{abstract}

International research journal of engineering, IT \& scientific research (C) 2021. This is an open access article under the CC BY-NC-ND license (https://creativecommons.org/licenses/by-nc-nd/4.0/).

\section{Corresponding author:}

I Gusti Agung Ayu Ratnawati,

Physics Faculty of Mathematics and Natural Sciences, Udayana University, Denpasar, Indonesia.

Email address: ratnawati@unud.ac.id

\footnotetext{
${ }^{a}$ Physics Faculty of Mathematics and Natural Sciences, Udayana University, Denpasar, Indonesia

b Physics Faculty of Mathematics and Natural Sciences, Udayana University, Denpasar, Indonesia

c Physics Faculty of Mathematics and Natural Sciences, Udayana University, Denpasar, Indonesia 


\section{Introduction}

Currently, in the world of medicine, the use of medical devices is very important. Along with the development of technology, the need for imaging in radiodiagnostics is getting higher. This can be seen from the increasing trend of using medical devices by experts that are tailored to the needs of patients. The progress of radiological examination is growing rapidly along with the progress of other sciences which is influenced by the development of technology, physics, chemistry, biology, electronics, computers, and so on. As for some of these examinations is the use of radiation sources, one of which is by using a CT-Scan (Lundstedt et al., 1998; Marini \& Walczak, 2015).

Almost all hospitals in the world use CT-Scan tools to diagnose patients who have injuries to their organs by emitting X-rays of the patient's body parts to be diagnosed (Sofiana, 2012). X-ray radiation gives rise to radiation called ionizing radiation, which can form ions by removing orbital electrons from atoms and interacting with them. Due to this ionization process, the material through which the radiation passes will form pairs of positive and negative ions. Some of the detrimental effects that appear on the human body due to exposure to X-rays are somatic effects in the form of damage to body tissue cells and genetic damage in the form of mutations of reproductive cells, stochastic effects, and deterministic effects (Rusmanto, 2016). In this study, to determine and analyze the radiation dose received by CT-Scan Thoracic (chest contrast) patients with the category of adults (15 years and over) with male and female gender at the Sanjiwani General Hospital, Gianyar.

\section{Materials and Methods}

The research used secondary data from the results of the examination of patients with chest contrast CT-Scan consisting of 2 categories, namely female and male patients with an adult age range ( $\geq 15$ years). Patient identification information that is needed other than age group is gender and weight (Peloquin, 1997; Weitschies et al., 2010). Each type of examination requires data of at least 10 patients for each type of examination that is infrequent or infrequent and 20 patients for each type of examination that is frequent or multiple (Ibrahim et al., 2018). If the facility can estimate the patient's workload per type of examination for each modality, then the number of patient samples required is at least $30 \%$ of the workload.

For a chest contrast CT scan, the estimated patient dose can be identified using CTDI $\mathrm{Vol}_{\text {and DLP. CTDI }}$.ol and DLP values can generally be seen on the CT Scan console monitor screen or integrated with the DICOM data system for each patient such as dose protocol reports or other features depending on the manufacturer (Klink et al., 2014; Hill et al., 2008). The research scheme carried out to facilitate the research process starts from patient medical

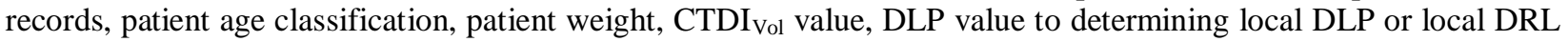
values which are then adjusted to the national I-DRL value as shown in Figure 1,

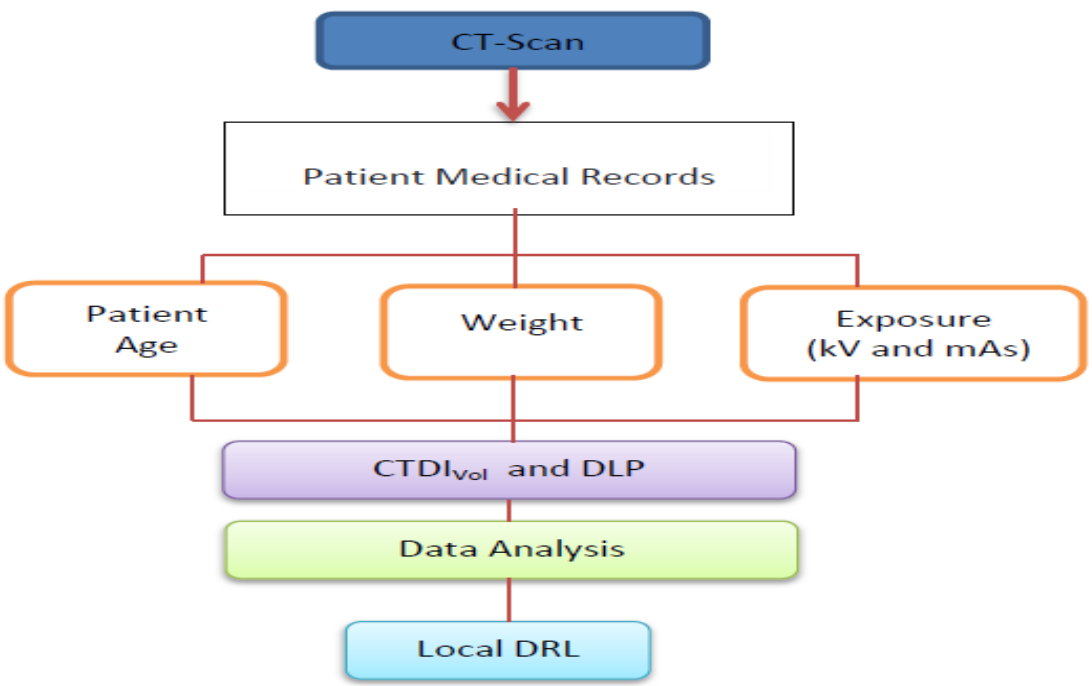

Figure 1. Research schematic

Ratnawati, I. G. A. A., Trisnawati, N. L. P., \& Sutapa, G. N. (2021). CT-scan patient dose monitoring on thorax examination in general hospital Sanjiwani Gianyar. International Research Journal of Engineering,

IT \& Scientific Research, 7(6), 214-218. https://doi.org/10.21744/irjeis.v7n6.1952 
After the dose data was obtained, an analysis was carried out using the distribution of the data with the 3rd quartile value (Q3=75 percentile). The value obtained in the 3rd quartile is then called the DRL value. This DRL value can be used as a reference or reference (baseline) in diagnostic and interventional radiology examinations, including CTScan examinations (Suryatika et al., 2020). To find the Q3 position of the patient dose distribution using the formula:

$$
n_{q 3=\frac{3(n+1)}{4}}
$$

While the value of Q3 is calculated using the formula:

Where:

$$
X_{q 3}=X_{a, 3}+\frac{1}{4}\left(X_{b, 3}-X_{a, 3}\right)
$$

$\mathrm{n}(\mathrm{q} 3)$ : 3rd quartile position

$\mathrm{n} \quad:$ the amount of data

$\mathrm{X}(\mathrm{q} 3)$ : 3rd quartile value

$\mathrm{X}(\mathrm{a}, 3)$ : observations before the 3rd quartile position

$\mathrm{X}(\mathrm{b}, 3)$ : observations after the 3 rd quartile position

\section{Results and Discussions}

The results of the examination of patients with chest contrast CT Scan in the category of female and male patients aged over 15 years, for $\mathrm{CTDI}_{\mathrm{Vol}}$ and DLP data taken from the DICOM data system for each patient such as the dose protocol report (Suandayani et al., 2020; Putra et al., 2020). Furthermore, the patient's CTDIVol and DLP data were sorted from the smallest data to the largest data, then analyzed using the data distribution with the 3rd quartile value (Q3=75 percentile), using equations 1 and 2 as follows:

$$
\begin{gathered}
n_{q 3=\frac{3(n+1)}{4}} \\
n_{q 3=\frac{3(20+1)}{4}=15,75}
\end{gathered}
$$

The position of the $3 \mathrm{rd}$ quartile is in the data sequence 16 , for CTDIVol $15.87 \mathrm{mGy}$ and DLP $816.66 \mathrm{mGy} . \mathrm{cm}$. So that the value of the 3rd quartile can be determined as follows:

and

$$
\begin{aligned}
X_{q 3} & =X_{a, 3}+\frac{1}{4}\left(X_{b, 3}-X_{a, 3}\right) \\
\text { CTDI }_{V^{\prime} l_{q 3}} & =15,28+\frac{1}{4}(17,32-15,28) \\
& =15,28+\frac{1}{4}(2,04) \\
& =15,79 \mathrm{mGy}
\end{aligned}
$$

$$
\begin{aligned}
D L P_{q 3} & =796,80+\frac{1}{4}(832,62-796,80) \\
& =796,80+\frac{1}{4}(35,82) \\
& =805,80 m G y
\end{aligned}
$$

The results of the analysis that have been carried out on the 3rd quartile values for CDTIVol and DLP can be expressed as the value of local DRL at Sanjiwani General Hospital Gianyar for chest contrast CT Scan examination in adult patients (Kadry et al., 2019; Xing et al., 2020; Suryatika et al., 2019). This value can be used as a baseline for diagnostic and interventional radiology examinations. This means that after the DRL value is set, the value is used as a comparison with the estimated dose received by the patient (Rusmanto, 2016).

Following BAPETEN Regulation no. 1211/K/V/2021, the Indonesian Diagnostic Reference Level has been set, hereinafter referred to as I-DRL, for the modalities of X-ray CT Scan and General Radiography (Silvia et al., 2013; Strauss \& Rae, 2012). For chest contrast, CT Scan examination, the I-DRL value at CTDI Vol was $16.00 \mathrm{mGy}$ and DLP was $810.00 \mathrm{mGy} . \mathrm{cm}$. The results of the research conducted indicate that the local DRL value is following the 
national I-DRL value. Thus, monitoring of the amount of dose received by patients at the Sanjiwani General Hospital, Gianyar, is well monitored in the next 1-2 years (Fukuda et al., 2017; Tomic et al., 2019).

\section{Conclusion}

Examination of adult patients ( $\geq 15$ years) for a chest contrast CT scan, the results showed a CTDIVol value of 15.79 mGy and a DLP of $805.80 \mathrm{mGy} . \mathrm{cm}$ which was the local DRL value of the Sanjiwani General Hospital, Gianyar. Where the local DRL value is following the national I-DRL value, based on BAPETEN Regulation No. 1211/K/V/2021.

Conflict of interest statement

The author declared that they have no competing interests.

Statement of authorship

The author has a responsibility for the conception and design of the study. The author has approved the final article.

Acknowledgments

Acknowledgments to Udayana University for funding the implementation of this research through the Unud PNBP in the fiscal year 2021 following the Letter of Appointment for the Study Program Leading Research (PUPS).

Ratnawati, I. G. A. A., Trisnawati, N. L. P., \& Sutapa, G. N. (2021). CT-scan patient dose monitoring on thorax examination in general hospital Sanjiwani Gianyar. International Research Journal of Engineering, IT \& Scientific Research, 7(6), 214-218. https://doi.org/10.21744/irjeis.v7n6.1952 


\section{References}

Adler, A., Carlton, R., \& Wold, B. (1992). A comparison of student radiographic reject rates. Radiologic technology, 64(1), 26-32.

Fukuda, A., Ichikawa, N., Fujita, Y., Lin, P. J. P., Matsubara, K., \& Miyati, T. (2017). Does gantry rotation time influence accuracy of volume computed tomography dose index (CTDIvol) in modern CT?. Physica Medica, 37, 43-48. https://doi.org/10.1016/j.ejmp.2017.04.008

Hill, B., Venning, A. J., \& Baldock, C. (2008). Polymer gel dosimetry on a multislice computed tomography scanner: Effect of changing parameters on CTDI. Physica Medica, 24(3), 149-158. https://doi.org/10.1016/j.ejmp.2007.11.005

Ibrahim, A. A., Abdullah, B., \& Halide, H. (2018). Estimasi Dosis Efektif Pasien Bagian Abdomen dari Hasil Pemeriksaan CT-Scan Merek Siemens SOMATOM. POSITRON, 8(2), 39-42.

Kadry, H., Wadnap, S., Xu, C., \& Ahsan, F. (2019). Digital light processing (DLP) 3D-printing technology and photoreactive polymers in fabrication of modified-release tablets. European Journal of Pharmaceutical Sciences, 135, 60-67. https://doi.org/10.1016/j.ejps.2019.05.008

Klink, T., Obmann, V., Heverhagen, J., Stork, A., Adam, G., \& Begemann, P. (2014). Reducing CT radiation dose with iterative reconstruction algorithms: the influence of scan and reconstruction parameters on image quality and CTDIvol. European journal of radiology, 83(9), 1645-1654. https://doi.org/10.1016/j.ejrad.2014.05.033

Lundstedt, T., Seifert, E., Abramo, L., Thelin, B., Nyström, Å., Pettersen, J., \& Bergman, R. (1998). Experimental design and optimization. Chemometrics and intelligent laboratory systems, 42(1-2), 3-40. https://doi.org/10.1016/S0169-7439(98)00065-3

Marini, F., \& Walczak, B. (2015). Particle swarm optimization (PSO). A tutorial. Chemometrics and Intelligent Laboratory Systems, 149, 153-165. https://doi.org/10.1016/j.chemolab.2015.08.020

Peloquin, C. A. (1997). Using therapeutic drug monitoring to dose the antimycobacterial drugs. Clinics in chest medicine, 18(1), 79-87. https://doi.org/10.1016/S0272-5231(05)70357-9

Putra, I. K. ., Ratnawati, G. A. A. ., \& Sutapa, G. N. . (2020). Monitoring of patients using radiodiagnostic do sage EI (Exposure Index) on CR (Computed Radiography). International Research Journal of Engineering, IT \& Scientific Research, 6(6), 45-49.

Rusmanto, (2016), Technical Guidelines for the Preparation of the National Diagnostic Reference Level (DRL), Center for the Study of Systems and Technology for Supervision of Radiation Facilities and Radioactive Substances of the Nuclear Energy Supervisory Agency.

Silvia, H., Milvita, D., Prasetio, H., \& Yuliati, H. (2013). Estimasi Nilai Ctdi Dan Dosis Efektif Pasien Bagian Head, Thorax Dan Abdomen Hasil Pemeriksaan Ct-scan Merek Philips Briliance 6. Jurnal Fisika Unand, 2(2).

Sofiana L., Johan A.E N. and Normahayu I., (2012), Estimation of Effective Dose in Multi Slice Ct-Scan Examination of Head and Abdomen Based on ICRP Recommendation 103, Department of Physics, Faculty of Mathematics and Natural Sciences Universitas Brawijaya.

Strauss, L. J., \& Rae, W. I. (2012). Image quality dependence on image processing software in computed radiography. SA Journal of Radiology, 16(2).

Suandayani, N. K. T., Sutapa, G. N., \& Kasmawan, I. G. A. (2020). Quality control of X-rays with collimator and the beam alignment test tool. International Journal of Physical Sciences and Engineering, 4(3), 7-15.

Suryatika, I. B. M., Anggarani, N. K. N., Poniman, S., \& Sutapa, G. N. (2020). Potential Risk of Cancer in Body Organs as Result of Torak CT-scan Exposure. International Journal of Physical Sciences and Engineering, 4(3), $1-6$.

Suryatika, I. B. M., Sutapa, G. N., \& Kasmawan, I. G. A. (2019). Radiology patient dosage monitoring for local diagnostic reference level. International Research Journal of Engineering, IT \& Scientific Research, 5(5), 26-31.

Tomic, N., Papaconstadopoulos, P., Bekerat, H., Antunovic, G., Aldelaijan, S., Seuntjens, J., \& Devic, S. (2019). Monte Carlo simulations of different CT X-ray energy spectra within CTDI phantom and the influence of its changes on radiochromic film measurements. Physica Medica, 62, 105-110. https://doi.org/10.1016/j.ejmp.2019.04.015

Weitschies, W., Blume, H., \& Mönnikes, H. (2010). Magnetic marker monitoring: high resolution real-time tracking of oral solid dosage forms in the gastrointestinal tract. European Journal of Pharmaceutics and Biopharmaceutics, 74(1), 93-101. https://doi.org/10.1016/j.ejpb.2009.07.007

Xing, B., Cao, C., Zhao, W., Shen, M., Wang, C., \& Zhao, Z. (2020). Dense 8 mol\% yttria-stabilized zirconia electrolyte by DLP stereolithography. Journal of the European Ceramic Society, 40(4), 1418-1423. https://doi.org/10.1016/j.jeurceramsoc.2019.09.045 